\title{
Guidelines for Hiring a Florida-Friendly Landscape Professional'
}

\author{
Esen Momol, Claire Lewis, Tom Wichmann, Elisha Cash, Jennifer Marvin, Michelle Atkinson, \\ Julie McConnell, Kristina McIntyre, Chris Marble, Bryan Unruh, Lynn Barber, Stacie Greco, \\ Ben Bolusky, Merry Mott, Deirdre Irwin, Betsy McGill, Cheryl Harris, Emily Brown, Michael \\ Scheinkman, and Amanda Peck²
}

This document is intended to provide guidance to residents and entities such as HOA community associations when hiring a landscape professional.

Florida-Friendly Landscaping ${ }^{\mathrm{TM}}$ (FFL) is the state of Florida's premier Extension program that promotes sustainable alternatives to "conventional" landscaping, providing guidance on low-impact, environmentally friendly, sciencebased landscape practices that use less water and reduce pollutant loading to Florida waters. Since 1993, FFL has served Florida as a partnership between the University of Florida Institute of Food and Agricultural Sciences Extension (UF/IFAS Extension) and the Florida Department of Environmental Protection (FDEP).
The FFL approach is based on the 9 FFL Principles: (1) Right Plant, Right Place; (2) Water Efficiently; (3) Fertilize Appropriately; (4) Mulch; (5) Attract Wildlife; (6) Manage Yard Pests Responsibly; (7) Recycle; (8) Reduce Stormwater Runoff; and (9) Protect the Waterfront. The overall goal is to reduce nonpoint source pollution through UF/IFASrecommended fertilization, irrigation, and pesticide use on residential and commercial landscapes.

The Florida-Friendly Landscaping ${ }^{\mathrm{TM}}$ (FFL) Program offers two professional certifications to help ensure that current and future Florida landscapes are sustainable and resilient, the Green Industries Best Management Practices (GI-BMP) and the Florida-Friendly Landscaping ${ }^{\mathrm{TM}}$ Certified Professional (FFLCP).

1. This document is ENH1350, one of a series of the Environmental Horticulture Department, UF/IFAS Extension. Original publication date February 2022. Visit the EDIS website at https://edis.ifas.ufl.edu for the currently supported version of this publication.

2. Esen Momol, director, UF/IFAS Florida-Friendly Landscaping ${ }^{\mathrm{TM}}$ Program; Claire Lewis, statewide FFC coordinator, UF/IFAS Florida-Friendly Landscaping ${ }^{\mathrm{TM}}$ Program; Tom Wichmann, assistant director and statewide GI-BMP coordinator, UF/IFAS Florida-Friendly Landscaping ${ }^{\mathrm{TM}}$ Program, UF/IFAS Center for Land Use Efficiency; Elisha Cash, GI-BMP regional coordinator, UF/IFAS Florida-Friendly Landscaping ${ }^{\text {TM }}$ Program; Jennifer Marvin, statewide FYN coordinator, UF/IFAS Florida-Friendly Landscaping ${ }^{\mathrm{TM}}$ Program; Michelle Atkinson, Extension agent II, MS, environmental horticulture, UF/IFAS Extension Manatee County; Julie McConnell, Extension agent II, MS, UF/IFAS Extension Bay County; Kristina McIntyre, Extension agent I, MS, Florida-Friendly Landscaping ${ }^{\text {TM }}$, UF/IFAS Extension Seminole County; Chris Marble, associate professor, Environmental Horticulture Department; Bryan Unruh, professor and associate center director, Environmental Horticulture Department, UF/IFAS West Florida Research and Education Center; Lynn Barber, program county Extension agent II, Florida Friendly Landscaping ${ }^{\mathrm{TM}}$, UF/IFAS Extension Hillsborough County; Stacie Greco, water conservation coordinator, Alachua County Environmental Protection Department; Ben Bolusky, chief executive officer, Florida Nursery, Growers \& Landscape Association; Merry Mott, director of certifications and career development, Florida Nursery, Growers \& Landscape Association; Deirdre Irwin, water conservation coordinator, St. Johns River Water Management District; Betsy McGill, executive director, Turfgrass Producers of Florida; Cheryl Harris, executive director, Florida Irrigation Society; Emily Brown, project manager, nonpoint source education coordinator, FDEP; Michael Scheinkman, project manager, nonpoint source education coordinator, FDEP; and Amanda Peck, program administrator, Nonpoint Source Management Program, FDEP; UF/IFAS Extension, Gainesville, FL 32611.

The Institute of Food and Agricultural Sciences (IFAS) is an Equal Opportunity Institution authorized to provide research, educational information and other services

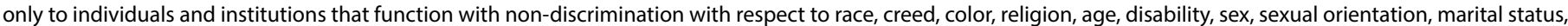

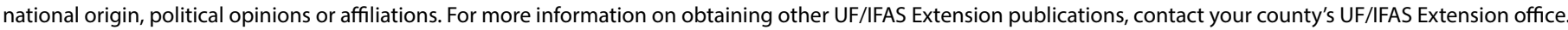
U.S. Department of Agriculture, UF/IFAS Extension Service, University of Florida, IFAS, Florida A \& M University Cooperative Extension Program, and Boards of County Commissioners Cooperating. Andra Johnson, dean for UF/IFAS Extension. 
1. The Green Industries Best Management Practices training program is legislatively mandated for those landscape professionals who apply fertilizer commercially.

2. The Florida-Friendly Landscaping ${ }^{\mathrm{TM}}$ Certified Professional is a voluntary certification for individuals who have completed the required training in FFL principles and are familiar with the latest UF/IFAS recommendations.

Professionals who are educated in and practice FloridaFriendly Landscaping ${ }^{\mathrm{TM}}$ (FFL) will set your landscape up for success. Plants, when selected, planted, and maintained sustainably, can live longer and resist pests, saving money over the long term.

Many residents evaluate their landscape professionals on price alone; however, healthy and sustainable landscapes are an investment in your property. Knowing what qualifications to look for when hiring a landscape professional will help you get the most for your investment, ensure your yard reaches its greatest potential, and protect Florida's water and other natural resources.

\section{Helpful Resources}

- Checklist for Hiring a Landscape Professional

- Recommended Certificates and Certifications

- FFL Example Photos

\section{Evaluate Your Needs}

Your search for a landscape professional should begin with an evaluation of your landscape needs and wants. When evaluating, consider your immediate and future needs, the desired visual aesthetic or "look" of the landscape, and the tasks that you are willing to do yourself versus the ones you want to pay a professional for.

Research local options and compare them. Look for companies with experience in the services you are seeking and strong references from past clients with the same or similar needs that you have. Check websites, social media profiles, and online reviews.

Make sure you note the services you need and want and clearly convey this to your potential landscape company. When interviewing professionals, they may suggest other services that you are not familiar with or may not even need. Some questions to consider may be:

- Are you looking for a lawn service company to mow your lawn regularly, or do you require additional services like weeding, pruning, planting seasonal flowers, pest control, and fertilization?

- Do you need more specialized services, such as landscape design and irrigation installation or repairs?

\section{Select a Landscape Professional}

When selecting a Florida-Friendly landscape professional, the most important question to ask is if they follow the nine FFL Principles. For a more detailed conversation about how a landscape professional implements the nine FFL principles, try using the Checklist for Hiring a Landscape Professional.

Additional things to consider when selecting a landscape professional:

- The contractor's Better Business Bureau rating.

- Relevant professional certificates and certifications.

- Memberships in professional associations.

- Guarantees of satisfaction.

- Testimonials and references from past and current clients.

- Pictures from past projects.

\section{Check If the Business Is Licensed and Insured}

Hire professionals who meet all state and local license and insurance requirements for the contracted work. Consult with your local UF/IFAS Extension agents about other appropriate insurance coverage.

- Workers' compensation insurance-verify coverage.

- General liability insurance-ask for proof of insurance.

Florida law requires licenses for specific services such as applying fertilizers or pesticides. Below is a list of licenses to be aware of when choosing a lawn service provider. Check with the company and use the links below to be sure they are properly licensed.

- Fertilization application: Limited urban commercial fertilizer applicator certification-verify limited fertilizer license.

- Pesticide (including herbicide) application: Certified pest control operator license holders or their ID cardholders can apply pesticides in turf and landscape bed areas. Limited commercial landscape maintenance pesticide license holders are restricted to apply in landscape beds only-verify pest control and pesticide licenses. 


\section{Certificates and Certifications for Landscape Professionals}

Depending on the type of work needed, there are a variety of qualifications to look for in a landscape professional. A professional does not need all the listed certifications, but if you have numerous trees or a complex landscape, you should consider the professional organizations that offer specialized certification and training. The following are common examples.

- Green Industries Best Management Practices (GIBMP) training certificate-verify GI-BMP credentials. The GI-BMP training program is managed by the FFL program and teaches proper landscape maintenance practices to landscape professionals. This training includes landscape management, irrigation, fertilization, and pesticide application information. The GI-BMP certificate is required for those who seek a state limited commercial fertilizer applicator license, and it is beneficial for all landscape professionals.

- Florida-Friendly Landscaping ${ }^{\mathrm{TM}}$ Certified Professional (FFLCP) - certified professional list. The FFLCP certification introduces participants to the nine principles of the FFL program as well as Florida-Friendly Landscaping ${ }^{\mathrm{TM}}$ design considerations and maintenance best management practices. These individuals are educated and trained to recognize and address common landscape issues by using environmentally sustainable landscape management practices that help preserve and protect Florida's natural resources.

- Florida Nursery, Growers and Landscape Association (FNGLA) certifications-verify FNGLA credentials.

- Certified Horticulture Professional (FCHP) program is the industry standard for measuring horticulture knowledge on everything from plant and pest identification to landscape management.

- Certified Landscape Technician (FCLT) program measures the skills of practicing landscape installation technicians.

- Certified Landscape Maintenance Technician (FCLMT) program measures the skills of practicing landscape maintenance technicians. This certification relies heavily on Green Industries Best Management Practices.

- Certified Landscape Designer (FCLD) program offers a professional designation for practicing landscape designers.
- Certified Landscape Contractor (FCLC) program is the highest level of certification available to Florida's landscape installation professionals.

- Certified Landscape Irrigation Service Technician (FCLIST) program measures skills specific to landscape irrigation service technicians.

- Florida Water Star ${ }^{S M}$ Accredited Professional (FWS-AP) certification-verify FWS-AP certification through FNGLA. Accreditation for landscape and irrigation professionals. FWS-AP has two designations: landscape and irrigation.

- Irrigation Association (IA) certification-verify IA certification. The Irrigation Association offers a number of certification programs for professionals specializing in turf, landscape, and golf irrigation.

- International Society of Arborists (ISA) certificationverify ISA certification. ISA Certified Arborists ${ }^{\circledast}$ are held to a code of ethics and are encouraged to follow industry standards.

\section{Professional Associations to Consider}

- National Association of Landscape Professionals (NALP)

- Florida Turfgrass Association (FTGA)

- Florida Pest Management Association (FPMA)

- Tree Care Industry Association (TCIA)

- Professional Grounds Maintenance Society (PGMS)

- Florida Irrigation Society (FIS)

\section{Checklist for Hiring a Landscape Professional}

Hiring a landscape professional who works best for your yard, your wallet and our environment does not need to be overwhelming. When hiring a landscape professional, use this checklist to keep track of the professional's qualifications and experience with Florida-Friendly Landscaping ${ }^{\mathrm{TM}}$. Select questions from this checklist to help you evaluate your prospective landscape professional.

Name of Company:

Work to be Performed: 


\section{Are they licensed and insured?}

The following questions can be asked over the phone prior to the site visit.

\begin{tabular}{|c|}
\hline Workers' Compensation Insurance-Verify workers' comp insurance. \\
\hline General Liability Insurance-Ask for proof of insurance. \\
\hline $\begin{array}{l}\text { Fertilizer Applicator License-Verify fertilizer applicator license (please note this is the same search application as the "Licensed } \\
\text { Pesticide Applicator Search"). } \\
\text { Fertilizer applicators are required in Florida to have a Limited Commercial Fertilizer license. }\end{array}$ \\
\hline $\begin{array}{l}\text { Pest Control-Verify pest control license. } \\
\text { Determine whether your landscape professional has the appropriate licensure for pesticide application for your landscape. } \\
\text { Certified Pest Control Operator License holders or their ID cardholders can apply pesticides in turf and landscape bed areas. } \\
\text { Limited Commercial Landscape Maintenance Pesticide License holders are restricted to apply in landscape beds only. }\end{array}$ \\
\hline
\end{tabular}

\section{Do they have additional certifications?}

\begin{tabular}{|l|l|}
\hline Green Industries Best Management Practices (GI-BMP) certification-Verify GI-BMP certification. \\
\hline Florida-Friendly Landscaping ${ }^{\text {TM }}$ Certified Professional (FFLCP)—Verify FFLCP certification. \\
\hline Florida Nursery, Growers and Landscape Association (FNGLA) certifications-Verify FNGLA credentials. \\
\hline Florida Water Star ${ }^{\text {SM }}$ Accredited Professional (FWS-AP) certification-Verify FWS-AP certification through FNGLA. \\
\hline International Society of Arborists (ISA) certification-Confirm ISA credential. \\
\hline Other: \\
\hline
\end{tabular}

\section{Questions and Observations for Your Landscape Professionals}

The following questions and observations can serve as a helpful tool when consulting with a landscape professional and ensuring they use Florida-Friendly Landscaping ${ }^{\mathrm{TM}}$ principles in your yard. Review the checklist and select the questions that are relevant to your property in preparation for your conversation with potential landscapers.

\section{QUESTION FOR ALL LANDSCAPE PROFESSIONALS:}

Do they follow the nine Florida-Friendly Landscaping ${ }^{\mathrm{TM}}$ Principles?

\section{IRRIGATION-Does the landscape professional:}

Calibrate irrigation systems to apply $1 / 2$ to $3 / 4$ inches of water per application?

Check rotor zones for matched precipitation?

Set the irrigation controller schedule to meet the water management district rule and local restrictions (if applicable)?

Maintain irrigation systems seasonally to adjust spray patterns and check for clogs and leaks?

Check the rainfall shut-off devise/soil moisture sensor for functionality?

Install sprinkler heads to rise above the turfgrass height?

A minimum 6-inch pop-up for spray heads and 4-inch pop-up for rotor heads in St. Augustinegrass, Zoysiagrass and Bahiagrass.

A minimum 4-inch pop-up for spray and rotor heads for Centipedegrass, Bermudagrass and Seashore paspalum.

Recommend microirrigation for planting beds? 


\section{MOWING—Does the landscape professional:}

Mow grass at the appropriate height?

The appropriate height depends on the type of grass. For example, standard St. Augustinegrass should be maintained around three to four inches. Landscapers should never cut more than $1 / 3$ of the grass height at a time.

Keep grass clippings in the lawn area (e.g., do they clean off equipment and keep grass clippings off roads and sidewalks and out of storm drains)?

Break up large clumps of grass clippings?

\section{PRUNING/TRIMMING—Does the landscape professional:}

Ensure hedges and shrubs are pruned to keep the bottom wider than the top?

Use the three-point cut method to prevent damage while pruning tree branches?

Use the "9:00 and 3:00" method to prune palm trees?

Check state and local rules before pruning or removing mangrove trees?

Sterilize equipment between job sites?

Use hand pruners on shrubs to obtain a healthy more natural appearing plant?

\section{TURF FERTILIZATION APPLICATION-Does the landscape professional:}

\begin{tabular}{|c|c|}
\hline \multirow[t]{9}{*}{ WHAT TO APPLY } & Follow UF/IFAS fertilizer recommendations for fertilizer rates and products? \\
\hline & Follow all local fertilizer ordinances? \\
\hline & Use slow/controlled-release products? (Check local restrictions for percent required) \\
\hline & Use soil tests to determine fertilizer needs? \\
\hline & Adjust fertilizer rates to account for nutrients in the water if irrigating with reclaimed water? \\
\hline & Read and follow fertilizer label instructions? \\
\hline & Avoid using combination products like weed and feed that contain both fertilizer and pesticides? \\
\hline & Does the professional explain what products are being used and why in a way that is understandable? \\
\hline & $\begin{array}{l}\text { Does the professional adjust fertilizer applications or rates seasonally or according to need and do they explain the work in } \\
\text { an understandable way? }\end{array}$ \\
\hline \multirow[t]{4}{*}{ HOW TO APPLY } & Use a broadcast spreader with an operational deflector shield? \\
\hline & Follow best management practices for calibrating the fertilizer spreader? \\
\hline & Sweep grass clippings, fertilizer and soil away from driveways and streets and back onto the lawn? \\
\hline & Avoid applying fertilizer in the low-maintenance zone adjacent to any water body? (Check local requirements.) \\
\hline \multirow[t]{4}{*}{ WHEN TO APPLY } & Fertilize only when grass is actively growing? \\
\hline & Avoid applying fertilizer for 30 to 60 days after planting new sod? \\
\hline & Follow all local fertilizer ordinances? \\
\hline & Avoid applying fertilizer when heavy rain is predicted or when soils are saturated? \\
\hline
\end{tabular}




\section{LANDSCAPE PLANT FERTILIZATION APPLICATION—Does the landscape professional:}

\begin{tabular}{|l|l|l|l|l}
\hline WHAT TO APPLY & Follow UF/IFAS fertilizer recommendations for fertilizer rates and products? \\
\hline & Follow all local fertilizer ordinances? \\
\hline & Use slow/controlled-release products? \\
\hline & Use soil tests to determine fertilizer needs? \\
\hline & Adjust fertilizer rates to account for nutrients in the water if irrigating with reclaimed water? \\
\hline & Read and follow fertilizer label instructions? \\
\hline & Avoid combination products that contain both fertilizer and pesticides? \\
\hline Fertilize palms with a UF/IFAS-recommended palm fertilizer? \\
\hline HOW TO APPLY & Follow best management practices for calibrating the fertilizer spreader? \\
\hline & Avoid applying fertilizer within 10 feet of any water body? \\
\hline WHEN TO APPLY & Contractor shall notify owner of any plant nutrient deficiency symptoms and what measures are recommended for \\
& correction. \\
\hline & Fertilizer may be required only if nutrient deficiencies are present in established plants. \\
\hline & Avoid applying fertilizer for 14 to 30 days after planting? \\
\hline & Follow all local fertilizer ordinances? \\
\hline
\end{tabular}

\section{PEST MANAGEMENT_Does the landscape professional:}

Regularly check landscape plants for pests?

Identify pests before considering a management plan?

Choose the least toxic treatment methods first?

Spot-treat the affected area rather than blanket spraying?

Use targeted pesticides rather than broad-spectrum products?

Follow pesticide label instructions?

Post notice of pesticide treatment?

\section{LANDSCAPE DESIGN—Does the landscape professional:}

\begin{tabular}{|l|l|}
\hline Locate plants in site conditions that are suited to their needs? \\
\hline Use the results of a soil test to guide plant selection? \\
\hline \begin{tabular}{l} 
Space plants based on their mature size? \\
\hline Select plants from the Florida-Friendly Landscaping
\end{tabular} \\
\hline Remove Plant Guide when designing the landscape? \\
\hline Group plants by their water needs? \\
\hline Plan turf areas to be functional and design them for easy maintenance? \\
\hline Define planting bed edges and shapes to make mowing easy? \\
\hline Use shrubs and groundcovers where grass is difficult to maintain? \\
\hline Position trees and shrubs to improve the building's heating and cooling capacity? \\
\hline Design landscape features that reduce runoff from the property (e.g., rain gardens, swales, berms)? \\
\hline Use porous materials for patios, driveways and walkways when possible? \\
\hline Use plants that provide a food source for birds and other wildlife? \\
\hline Use host and nectar plants for butterflies, hummingbirds and/or other pollinators? \\
\hline Retain existing clusters of vegetation in the design? \\
\hline
\end{tabular}




\section{PLANT INSTALLATION-Does the landscape professional:}

\begin{tabular}{|l|l|}
\hline Follow UF/IFAS planting guidelines? \\
\hline Select top-quality plants for installation? \\
\hline Ensure the main leader of shrubs are at least 2.5 feet away from the foundation of the home? \\
\hline Organic mulch is installed at two to three inches? \\
\hline Specify that mulch is pulled away from the base of trees, shrubs, and within 12 inches of the foundation? \\
\hline Use Florida-Friendly recommended mulches? \\
\hline Ensure plants are watered for establishment according to UF/IFAS guidelines? \\
\hline
\end{tabular}

